I Federal University of Rio Grande do Sul (UFRGS), Porto Alegre, RS, Brasil

claudialwfonseca@gmail.com.

II Federal University of Rio Grande do Sul (UFRGS),

Porto Alegre, RS, Brasil

helenafietz@gmail.com

\title{
COLLECTIVES OF CARE IN THE RELATIONS SURROUNDING PEOPLE WITH 'HEAD TROUBLES': FAMILY, COMMUNITY AND GENDER IN A WORKING-CLASS NEIGHBOURHOOD OF SOUTHERN BRAZIL
}

\section{INTRODUCTION}

Care, as practice and moral value, is characterized by its relational nature (Mol, 2008; Kittay, I999; Molinier, 20I2). While it is true that there are many ways of experiencing relations of care, there are likewise many networks that cut through them, among which we find family, institutional and community-based networks. On the basis of an ethnographic study carried out in a working-class neighbourhood of Porto Alegre, Rio Grande do Sul, Brazil, between 2014 and 20I5, we propose to examine in this article how these different networks interact.

Our original curiosity concerned the legal steps involved in declaring an adult mentally incompetent. Hence, we were lead to a certain community association to meet with Jurema, who at the time was considering interdicting her son, Jair. There, we met Edna and, eventually, Ligia who, like Jurema, were taking care of an adult relative with cognitive disabilities and were considering declaring them legally incompetent. As we followed their affairs and became acquainted with their daily rounds, we gradually came to realise that, more than worried about legal details, what was really at stake for all these women was guaranteeing the best possible care for those under their responsibility. We visited these women regularly for over a year, recorded in our field notes their daily interactions with family members and friends, and also their efforts (some successful, others less so) to create spaces for the promotion of the well-being of the adults with disability under their care. Our gaze consequently shifted to 
the nuances of these relations, to the multiplicity and complexity of the practices of care that the women engaged in.

Based on our experience in the field, ${ }^{\mathrm{I}}$ we will narrate the story of these three women responsible for the care of an adult relative considered legally "incapable of managing his or her own affairs", a condition resulting from what their caretakers perceive to be 'head troubles' (problemas de cabeça). The three cases - involving Black women between 65 and 75 years of age, living mostly off their retirement funds after a lifetime of working as cleaning ladies - allow us to consider specificities of gender, generation, class and ethnicity. At the same time, the study provides thought-provoking methodological reflections on the ethnography of care.

Our ethnographic material forced us to widen our scope, originally focused on the rights of people with disabilities, toward a consideration of the relations of care that buttress these rights. Contemplating these circuits of relations raised a number of questions. What happens when we take the notions of 'care' and 'dependency' in tandem, engaging them in all their complexity, contemplating the subject who suffers from 'troubles' as someone located "not inside the body but in the network of relations, affects, encounters" (Das, 2015: 87)? How are we to speak of 'family', 'community' and 'state' as though they were well-delineated figures when, in practice, these spheres show themselves to be inextricably interconnected? We suggest that the focus on daily situations of care highlights the fragility of preconceived categories, values and principles, blurring the very limits between 'good' and 'bad' care. Such categories and evaluations take on a meaningful existence only in contingent and local situations (Mol, 2008).

We draw inspiration from the rich discussion on theories of care (Hirata \& Guimarães, 20I2; Hirata \& Debert, 20I6). However, we deal only indirectly with certain classical themes of this literature, such as issues surrounding the sexual division of tasks, the invisibility of domestic work, the earnings and professionalization of care work and regimes of welfare (for instance, Razavi, 2007). Rather, we embrace the proposal of Dutch anthropologist Annemarie Mol (2008), who, following a long feminist tradition of critical thought, develops a distinctive model for the analysis of care. Gleaning inspiration from pioneer studies on the ethics of care (Tronto, I993; Bellacasa, 20II), anchored in the analysis of practices of care, and framed in a style that privileges narratives of daily scenes, the approach outlined by this author acknowledges the challenge, characteristic of feminist political theory, to interfere in the categories we use to comprehend the world.

Although we have organized this article in a linear sequence - beginning with ostensibly familial forms of care and moving on to those which are more evidently mediated by institutional policies and public services -, we do not mean to contrast 'traditional' modalities of care (often taken to be 'affective') 
with more modern ones (often taken to be 'rational'); nor do we intend to oppose 'community immersion' to 'personal autonomy'. On the contrary, and in consonance with the analytical approach proposed above, we circumvent dichotomous perspectives of analysis by drawing attention, above all, to the rich and multifaceted nature of a particular Western (and, in this case, Latin American) ethic of care that appears pertinent to the organization of daily life. Our approach thus seeks to sketch the contours of a 'moral economy' (Fassin, 20I2) that involves specialists, family, neighbours and any other actors who, in their daily affairs, deal with the challenge of caring for a dependent adult with 'head troubles'.

\section{A CHANGING CONTEXT: STATE POLICIES OF SUPPORT}

The context in which our observations took place has certain historical specificities. First, we should point out that, unlike Western European countries, Brazil (as other Latin-American nations), was never a 'welfare state' that effectively took on responsibility for dependent family members. Thus, one cannot speak of a 'return' of such responsibilities to the family, as has been occurring elsewhere in the contemporary neoliberal era (see, for instance, Yazici, 20I2). Historically, in Brazil, there were a number of large public institutions that sheltered the elderly, the disabled and people with severe mental health problems. Starting in the I970's, these asylums - which tended to be centralised in large capital cities and were often overcrowded - began to be portrayed in the media as "houses of horror", associated with the idea of helpless victims abandoned by their families, and were subsequently dismantled. Nonetheless, whether due to their bad reputations and deliberate shunning by potential patients or to sheer lack of space, these institutions never attended to more than a small percentage of the target population. Most adults with disabilities were traditionally cared for by family members, as, indeed, they are still today.

Secondly, structural conditions do not favour male participation in domestic life. In the poorer sectors of the Brazilian population, men rarely have stable jobs. It was only in the early 2000's that the number of Brazilian workers with regular employment surpassed those in the informal economy. In 20I6, with unemployment rates close to i I \%, still over one-third of the workforce were engaged in informal activities, and thus denied the benefits and guarantees of Brazilian labour laws. In other words, underemployment plagues a good number of men exactly at a moment in life when they are expected to provide for their families (Proni, 2013). It is no wonder that, in recent decades, the percentage of 'female heads of family' has remained stable at around $40 \%$ of all households.

The I 980 a and Ig9os witnessed the growth of a series of social movements, often backed by feminist lobbies, that demanded an increase of the state's presence in struggling families (Molyneux, 2000). During the I990s, the globalized anti-asylum movement resulted in the dismantling of Brazil's large 
mental institutions, with patients being gradually 'returned to society'. However, despite the intention of 'Centres for Psychosocial Attention' (CAPs, Centros de Atenção Psicossocial), designed to offer home treatment to people with mental health issues and/or intellectual disability (Lima \& Assis Brasil, 20I4), National Health Services were unable to formulate strategies that would assure, in practice, adequate assistance to ex-interns and the families that cared for them. It was only at the start of the twenty-first century, after the enactment of the 200I Law of Psychiatric Reform, that programmes providing financial and therapeutic support to patients who had previously been institutionalised were consolidated. For example, the 'Returning Home' (Volta para Casa) programme, implemented in 2003, stipulated the provision of monthly stipends to ex-interns (mental patients and ex-convicts) leaving institutionalized care. Despite these initiatives, one hears still today frequent complaints about the dearth of state services provided to families caring for those - particularly adults - with cognitive and intellectual disabilities.

After the Worker's Party (Partido dos Trabalhadores - PT) came to power in 2003, a series of incipient and fragmented policies were coordinated to try and maximise support given to families suffering from different sorts of 'social vulnerability'. The most well-known of these efforts was the Bolsa Família (a monthly family stipend), that, despite guaranteeing a monetary supplement for poor families with school-age children, has been the target of unrelenting criticism. On the one hand, accused of being a "political policy that is compensatory, residual, narrow and selective", it has been deemed "compatible with the accumulation of capital", and therefore unable to promote a more equitable redistribution of funds (Schmidt \& Silva, 20I5: 89, see also Lavinas, 20I4). On the other hand, because the stipend goes (preferably) to the mother of the family only on condition that her children follow a certain prescribed behaviour, the program has been criticised for reinforcing traditional gender stereotypes that overburden women with an accumulation of responsibilities (Molyneux, 2007; Esquivel, 20I I; Sorj, 20I6).

Nonetheless, at the time, other measures of social welfare came into being (such as an increase in the minimum salary) that brought palpable improvements to the living conditions of society's poorer sectors. One of the most important of these measures was the Benefício de Prestação Continuada (Continuous Cash Benefit), known as 'BPC', granting to the elderly and severely disabled living in poverty-stricken families a lifelong pension ${ }^{2}$. This right, established by the 1988 Constitution, was subsequently reiterated through legislative acts (1993) that lead to the first concrete policies in 1996. During the government of the Worker's Party, the BPC was extended to a large section of the population: between 2002 and 2014, the number of beneficiaries with disabilities doubled, and the number of elderly beneficiaries more than tripled. By 2014 , thanks to the BPC, more than four million people (2.257.967 with disabil- 
ities and I.888.028 elderly), or nearly $2 \%$ of the Brazilian population was receiving a viable income.

The expansion of state assistance is relevant, but still insufficient, for understanding the dynamics of community support for people with disabilities. It is telling that, despite being from low-income families, none of the three caretakers we describe were assisted by the local CAPs and two of them had cared for a person with disability for over 40 years with no state aide whatsoever. We thus propose to examine alternative networks of care that give support to these families, and that, as we will see, function more or less effectively according to circumstances.

\section{LÍGIA AND SILVANA: CIRCULATING WITHIN THE EXTENDED FAMILY}

Lígia, who has been caring for her niece Silvana for over ten years, offers an example of the networks of mutual support that traditionally exist within extended families. According to Margarida, one of Lígia's daughters whom we met at the Community Association, no one really knows what Silvana's 'trouble' is. She has been slow ever since she was a child, exhibiting a number of complications: she never learned to read or write, never had a job, and unless she is supervised by an adult she is likely to wander off into the streets, singing and dancing. Recently, when she was asked to buy bread, she was 'forgotten' in the bakery. Without voicing any protest whatsoever, she ended up spending the night locked in. For fear of other similar mishaps, Silvana mostly stays at home, leading a relatively secluded life.

Despite being 45 years old, the girl looks much younger. She is the biological daughter of Lígia's younger sister and an 'unknown father'. In order to avoid a family scandal, she was registered by her uncle and his wife. Silvana lived for most of her life with this couple, on the northern coast of Rio Grande do Sul, and it is the members of this nuclear family that she calls 'father', 'mother', and 'brothers'. According to Margarida, when Silvana's 'father' died, her 'mother' and 'brothers' wanted "nothing more to do with her". They dropped her off with some relative and just never showed up again. In her new home, Silvana was mistreated, she was always filthy and even "got slapped around". When she finally went to live with her aunt, Lígia, she did not even have an identity document.

For the last ten years or so, Lígia has been Silvana's primary caretaker, although her two daughters sometimes help her. As she readily admits, caring for Silvana is not easy. Her 'retardation' (retardo) prevents the girl from doing anything alone. She does not know how to brush her teeth, take a shower, or change her menstrual pads: "I try to teach her, I try, but she doesn't learn". The two women also must deal with financial problems, since they live off Lígia's retirement benefit of a monthly minimum wage. After paying for basic necessities, there's no money left over to pay for a bus fare, not even for Silvana to get psychiatric treatment in the nearby CAPs. 
In the year before our research started, Margarida had suggested taking Silvana to get her Identity Card and Social Security number in the hope of obtaining a Continuous Cash Benefit on her behalf. Lígia, however, was reluctant to pursue this point. She feared being accused of caring for Silvana only because of this (eventual) financial boost for the family budget. She worried lest Silvana's 'brothers' and 'mother' would be back for her once they learned she was receiving a monthly stipend, and that they would take her someplace where "she wouldn't be well cared for". Nonetheless, Lígia ultimately gave in, and the last time we visited this family Silvana was making plans for what she would do when the money finally started to come in. With a broad smile, she told us that first of all she would get her teeth fixed. Then she would buy a bus pass to "hang around her neck and walk around with". The rest she would give to her aunt, "who takes care of me".

Silvana's story speaks of a well-known tradition in extended families and close-knit communities, according to which the care of children and other dependents can be shared between different households. Widely described in Latin-American historiography (Fonseca I995, 2002; Moreno, 2013), the 'circulation of children' often involved the informal adoption of babies, children and even adolescents who, for one reason or another, would find themselves in want of care. ${ }^{3}$ Faced with a lack of day-care centres and the scant help available in state schools, placing children in proxy families remained for many years a welcome solution for 'female heads-of-households', forced to work long hours to make a living. For the family (in general only slightly better-off than the birth family) that took in such a child, caring for the youngster of a relative or neighbour in dire straits was seen to be an act of generosity with its own inherent rewards. As one woman who cared for a number of nephews, grandchildren, and neighbours reminded us: "Where one person eats, two or three more can fit it". ${ }^{4}$ When the system worked properly, the "raised children" (filhos de criação) were treated as if they had been born in the family; they called their caretakers 'mom' and 'dad' and enjoyed a status similar to that of a legally adopted son or daughter. A child could, however, be rejected by the new family and passed on to less compassionate people if he or she did not conform to expectations, ending up in a situation of vulnerability - as, indeed, happened to Silvana.

Although they had no legal obligation toward Silvana, Lígia and her two daughters were part of an extended-family effort to care for this person 'with problems' - because they believed she deserved proper care and because there was no other option. However, without the family's involvement in a wider network of support - including professional services available through the National Health System - Silvana's impairment seems to continuously limit her relations and way of life within a society that does not offer the means necessary for her to thrive. 


\section{DONA EDNA AND NINA: THE WEB OF RELATIONS EXPANDS TOWARDS THE COMMUNITY}

We met Dona Edna and her daughter Nina in March of 2014 in her neighbourhood's Community Association. As president of the association, Dona Edna is nearly always there, alongside her 48-year-old daughter, Nina, who because of her 'retardation' depends heavily on her mother. Now retired, Dona Edna is a pillar of her community - a person who 'knows her rights', who has transit in various public institutions, and does not hesitate to use her political clout for the good of the neighbourhood.

It is relevant to mention that, when she was young, Dona Edna had been herself in need of assistance. When her first husband died, she "gave away" her two children - one to her mother-in-law and the other to a family for whom she worked as a maid. With her second husband, she had three daughters, two of whom died in early childhood with no clear diagnosis of what ailed them. In fact, Nina is the only one of her five children that Dona Edna has raised. Separated early on from her third husband, Dona Edna took care of the girl alone. While still in childhood, Nina was diagnosed by doctors as having problems resulting from a bout of meningitis she had had as a baby. The girl has since suffered from seizures symptomatic of a type of epilepsy. She attended a local day-care centre, but at seven was expelled by her teacher who claimed she "acted crazy" and disturbed the other children.

When she was eight or nine years old, Nina was admitted to a children's hospital because of her seizures. It was an exhausting period for Dona Edna, who was obliged to split her time between her job as a full-time housemaid and trips to the hospital where she would entertain her daughter with favourite toys. The seizures only relented when the child started using Gardenal ${ }^{\mathrm{TM}}$, medication that she still takes each night before going to bed. When Silvana was discharged from hospital, she went to study at a special school in the middle-class neighbourhood where her mother worked. Dona Edna states categorically that, despite having been to school, her daughter "never managed to learn anything, because she simply can't". Nina is currently accompanied by the doctors in family medicine at the public health post close to where she lives.

Our observations suggest that, notwithstanding certain limitations, Nina is well-adjusted to her neighbourhood. It is not uncommon to see her opening the doors of the community association, especially on days her mother is tired or late. She enjoys inviting people in for coffee, and she is also responsible for much of the cleaning of the premises. As a hostess, she engages visitors in conversation about her many activities - her participation in Sunday church services, her appointments at the local health centre with the nutritionist who is helping her lose weight, her exercise classes in one of the city centre's parks, her almost daily visits to a local gym, the 'therapy' she had to undergo to obtain 
a special bus pass, and so on. When telling her stories, Nina peppers the conversation with news about her mother's health, asks after her interlocutors, and offers prayers for friends who are ill.

Through her routine and her habits, Nina makes it known that, although she is thoroughly dependent on her mother, she strives to expand and manage her network of relations. She carries out tasks on behalf of the association; she takes care of herself through exercise and dieting; she is attentive to the wellbeing of her friends and worries that her mother works too hard. Within her limits, Nina helps out, participates and cares - possibilities that are coproduced by Nina, her mother, neighbours and public services which provide support.

Nina never leaves the neighbourhood without the company of someone to guide and protect her. In contrast, within the neighbourhood she moves about by herself, with nothing but the moral protection of her mother and the familiarity of neighbours to guarantee her safety. As a regular at the Association comments, “We like her a lot, but she's a child. She can't work, can't maintain herself, depends on Dona Edna for everything. She gets around OK, she does her things, but only because she knows the neighbourhood and because everyone knows her in these parts. Otherwise she wouldn't be able to".

It should be acknowledged that Dona Edna is not just any neighbour. She has been the head of the neighbourhood association for some time. Among her many functions is the dissemination of information about different public services available to the population. Representing the neighbourhood in a number of municipal forums, she is well-known and respected by the authorities. In other words, although she remains a person of modest means living precariously, Dona Edna's social and symbolic capital ensure a greater range of possibilities for Nina. Recently, overcoming certain technical restrictions, Dona Edna secured a Continuous Cash Benefit for her daughter, allowed the girl to make plans for extending her range of daily activities and for making new friends. Closer to home, Dona Edna has sufficient influence to keep under control the local youth whose mocking jeers might otherwise offend her daughter. We can clearly see, through the example of this family, how the efforts and capabilities of an entrepreneuring mother provide the link between Nina and the community's support.

This story of Nina and her mother illustrates a subtle nuance of care underlined by Annemarie $\mathrm{Mol}(2008,2010)$. The author proposes that, contrary to the 'logic of choice', bolstered by notions such as 'autonomy' and 'individual choice', the 'logic of care' does not operate through individuals, but through collectives. As she understands it, the notion of 'collectives' refers to the fact that people are part of myriad associations which are constantly made, unmade and remade. The different possibilities involved in these associations are inherent to the practice of care; for this practice to be effective, it must take into account the different collectives to which a subject belongs. From this vantage 
point, the subject is always relational, that is, composed of the numerous relations that precede it: "the individuals who figure in the logic of care would die if they were left alone. They owe their very ability to act to others" (Mol, 2008: 62). The issue is not that of 'equality' within these relations, but rather of a series of non-hierarchical differences: "horizontal differences between people", differences that indicate different needs and, more specifically, different needs for care (Mol, 2008: 62). Choice thus comes to depend on a circuit of relations, and not on a specific capacity or power of certain people. ${ }^{5}$

Although Nina and Silvana are perceived by those around them to share similar problems - they fall into the same age group, both live in the same region, are deemed 'slow', victims of 'head troubles' that render them dependent on their caretakers -, the possibilities available to them have not been equal. Lígia was unable to follow Silvana's childhood development; they have only lived together for ten years and the former does not yet have any legal authority or responsibility toward her niece. Although the care she provides is evidently earnest and affectionate, it can also be considered more 'basic': she looks after Silvana's daily necessities - housing, hygiene, meals - and attends to her identity documents. Nina, in contrast, has always lived with her mother and, ever since she was a baby, she has been attended by doctors and other specialists dedicated to improving her quality of life. But this is not all. The example of Dona Edna and Nina suggests that, in the particular collectives of care that shape the limits and liberties afforded a person with disability, the caretaker's talent for political mobilization and integration into the community emerge as fundamental factors.

\section{JUREMA AND JAIR: WHEN THE CARE NETWORK REVEALS ITS FRAGILITY}

We have been following examples of women of a certain age who make use of strategies in both informal and institutional networks in order to guarantee adequate care for a dependent adult with 'head troubles'. The third example, in which the sex of the dependent person and the nature of his 'troubles' are different, reveals a situation in which the resources available to the mothercaretaker prove to be relatively inadequate. Here, we find a circuit of relations that, while marked by diverse institutional interventions, is permeated by an ambivalence inherent to the logic of care (Mol, 2008): since the definition of 'adequate' care is always local and contingent, where does one locate the thin line between 'care' and 'negligence'?

Jurema, vice-president of the neighbourhood Association, has trouble walking because of knee problems. Having worked most her life as a housemaid, she currently lives off her retirement funds and a small pension left her by her father (who had worked as a civil servant). Already on our first encounter, Jurema told me the story of Jair, her only son. He had spent I 6 of his 44 years in prison for homicide, in a facility some $60 \mathrm{~km}$ from Porto Alegre. While he was 
incarcerated he was diagnosed with schizophrenia and bipolarity, as well as being a drug user. After serving his sentence, he spent a further three years in the Forensic Psychiatric Institute (Instituto Psiquiátrico Forense - IFP) of Porto Alegre. To facilitate his adaptation after release, the professional team at the institute made sure he received the benefits to which he was entitled: along with the BPC for "people with disabilities", he also obtained the "Returning Home' benefit ${ }^{6}$.

As soon as her son left the IFP, Jurema used the money from his benefits to rent and furnish a small place for him. She would visit him frequently, ensuring that he had food and clothing and was taking his medications. Jair soon went back to living on the streets, however, where we found him at the time of fieldwork. Although he had never been legally interdicted, his mother kept his documents and bank cards "so that he doesn't spend everything on drugs". In return, Jurema would go looking for her son in the streets two or three times a week, providing him with a home-cooked meal, clean clothes, and one or two boxes of candy.

Jurema insists that she has always cared for Jair. When he was a child, she would often take him along to her workplace. Once, she even quit a job when her employer forbade her to bring the boy with her. She had not choice, she says, “because I couldn't be there with my employer's kids, thinking that my son was alone in the streets, maybe turning into a crook". Having noticed disturbing trends in his behaviour, she even took him to the state's Psychiatric Hospital for a while. When she speaks of her son's childhood, Jurema is very much on the defensive - no doubt because she has often been held responsible for his troubles: “People say I don't give him proper care, that I didn't take good care of him when he was little, but it's because they don't know [...]. Jair wasn't supposed to turn out like he did".

Although she insists her son was unjustly condemned for a crime he did not commit, she acknowledges that he is sometimes violent. Jurema even had to move house and keep her address secret so as to avoid the threat of his physical outbursts. At present, she has to deal with complaints from shop owners on the street where her son hangs out. They say that, besides accumulating unsightly piles of rubbish around his campsites, he harasses women customers and vandalises public property.

Jair is looked after by the 'health people': a social worker and a doctor, both employed by the city centre's 'model' health post. On one of the occasions we visited Jair, we found a pair of social educators trying to convince Jurema that her son was unwell, that he was not taking his medication, and that his schizophrenia was probably out of control. They tried to convince her that perhaps it would be best if Jair were admitted to a hospital. There, he would have access to free care for his addiction for up to the legal period of 2 I days, and afterwards he could be transferred to a private clinic paid out of the BPC 
he receives. But Jurema was fed up with what she saw as completely ineffective interventions, claiming that every time her son went to some clinic he would return to the streets even worse off than he was before.

Jurema had tried to hospitalize Jair no fewer than four times in five years. The first time he spent some five months in a clinic on the outskirts of Porto Alegre. Jurema had found the place through the owner - a 'religious' man, linked to the same Afro-Brazilian religion that Jurema had practiced for years. However, Jair ended up running away with the owner's wife, and later went back to using drugs. The following year, he entered a therapeutic community run by the Evangelical Universal Church of the Kingdom of God (Igreja Universal do Reino de Deus), at the cost of half a minimum wage per month. His mother and aunt would visit him every Sunday. For the first three months, Jair seemed to be doing well. His mother even caught a glimpse of a true vocation in her son: he "prayed, closed his eyes, really believed". During the last three months of his time there, however, his behaviour changed. In the room where patients met with their families, he would seek out a corner far from everyone else and spend the whole visit begging his mother to get him out.

When Jair returned once again to the streets, Jurema went to court to solicit his compulsory internment and treatment for drug addiction. Thanks to a favourable verdict, her son spent 2 I days in the specialised sector of a public hospital. His mother recalls the day the court bailiff went to the street where Jair lived to take him away. The man went about everything in a calm and profes sional manner, convincing Jair to accompany him to the hospital. Upon arrival at the institution, however, Jair had a violent outburst and had to be contained by the security guards. Considered a threat to himself and to others, he had to be tied to the bed and, after some time, started yelling "Mom, mom, get me out of here! Don't leave me in this place."

On the many occasions Jurema narrated this episode, her voice would inevitably crack. But, despite her anguish, she had left her son in treatment for the period determined by the judge. When Jair finally left hospital, his mother insists he was worse than when he had been admitted - convincing her that the $2 \mathrm{I}$-day treatment was worthless.

Thus, when the social educators or other members of the administrative team that care for Jair recommended internment, Jurema's past experience assured the firmness of her reply: anything done against his wishes would achieve nothing. Later, when alone with us, she confessed how much she worried about her son's well-being, particularly as winter approached. But she was too tired to deal with the stress and effort needed to commit her son once again, without any real hope of improvement.

The story of Jair and Jurema depicts an extreme situation that lacks a neat solution, thus making it an apt illustration for the notion of 'enacted good', coined by Mol, Moser and Pols (20I0). The term underlines the fact that care 
does not operate according to clear rules (like 'justice', for example), nor does it follow the measured calculations of some abstract principle of reciprocity. It is, above all, something that people invent and reinvent in the process of everyday practices - practices embedded in complex and ambivalent stories in which 'good' and 'bad' are not always seen as separate entities:

Good and bad may be intertwined; good intentions may have bad effects; if one looks hard enough any particular 'good' practice may hold something 'bad' inside it (and vice versa); 'good enough' care may be a wiser goal than care that is 'ever better'; while sometimes it is simply unclear whether (for whom, to what extent, in which way) some form of care deserves to be praised or to be criticised (Mol, Moser \& Pols, 2010: I2-13).

Jurema's varied efforts to help her son are consistent with what Mol (20I0) calls 'tinkering', which is an essential element in practices of care that rely on an experimental, frequently improvised way of acting. It applies to situations in which different definitions of 'good' (each reflecting certain values and ways of ordering reality) come into play. In this way, care can be understood as a combination, a set of tinkering practices, in which actions and decisions are always contingent, adapted to a momentary reality. The goal of care is not necessarily held constant through time. A certain type of care cannot be taken as an absolute solution to a given situation. Each act of care is part of a continuous process, an experiment that unravels in a way that is attentive to the different needs (and resources) that are present in a specific space and time.

This difficulty in defining 'good' and 'bad' care is well illustrated by the disputes we have described between Jurema and the social educators. Everyone's ultimate aim was the same: to guarantee the best solution for Jair's situation. Jurema and the social educators all had Jair's well-being in mind. However, 'well-being' meant different things to each party. While Jurema considered that an adequate solution had to include respect for her son's own wishes, the social educators were convinced that only institutional commitment (whether compulsory or induced) would make Jair better. Different and conflicting meanings of care were made evident, and ultimately Jurema's will prevailed, since she was Jair's mother. Nonetheless, it is worth reflecting a moment on this maternal responsibility and on how a woman becomes both ultimate authority and scapegoat in situations like this.

\section{WOMEN IN COMMUNAL ORGANIZATION}

The success of Brazil's feminist social movements has been well documented in the academic literature. Since the I980s and I990s, in "productive synergy with state agencies", these movements have promoted an agenda of female empowerment, focusing particularly on combating domestic violence against women (Molyneux, 2000: I94). Starting in the I990s, certain working-class women in cities such as Rio de Janeiro and São Paulo joined forces in the strug- 
gle against the police violence that threatened the survival of their children (Leite, 2004; Vianna \& Farias, 20 I I). Researchers further highlight how Brazilian working-class women have assumed a strategic prominence in recent years, "whether as the preferential beneficiaries of programmes that combat intergenerational poverty, such as cash-transfer programmes, or as operators, at the local level, of government programmes geared toward those who are considered most vulnerable" (Sorj \& Gomes, 20I I: I48, see also Bonetti, 2007; Pires \& Rego, 2013). And one finds in certain government documents an emphasis on the importance of a 'feminist economy' run by women - an economy that would be less individualistic and more solidary than the present market economy (Secretaria..., 20I6).

In Porto Alegre, there is a long history of 'popular involvement' in city and state government, due to a great extent to the pioneering 'participatory budget' programme begun in the I99os. Feminist militancy, which encouraged the participation of lower-income women in local politics, occupies a privileged place in this history (Bonetti, 200I). In recent years, the professionalization of NGOs and state sponsorship of social movements have resulted in a reconfiguration of this scenario (Junge, 20I2). Nonetheless, there are still countless small community organizations - more often than not led by women - which stand at the front lines of an economy of care (see Ahlert, 2008; Brites \& Schabbach, 2014; Junge, 2017).

With Dona Edna and Nina, we saw the tremendous importance of a woman's political participation in order for her to maximize the benefits provided by public services. Jurema is also a community leader. Retired, most of her effort goes to the association, where she can be found every weekday from early morning to late at night. She also participates in civic meetings and events organised by different agencies, municipal and state boards and social movements. Aside from all her other activities, Jurema makes a point of participating in courses that confer a certificate, and always reminds us that she has a file at home with all the certificates she has earned. She has, for instance, training in the care of elderly people, in community leadership, and in some basic computer skills. As far as her relationship with Jair goes, however, political mobilization is simply not enough to solve the difficulties of providing care. The problem is not lack of material resources: Jurema has her own stable income, and her son receives two monthly benefits - more than enough to pay for the health treatments he might need. It is simply that, given the existing resources, Jair's compounded problems defy the possibility of a definitive 'solution'.

Although it is not uncommon to find networks of mutual aid among women (such as in Ligia's case), none of the three caretakers described in this article can count on the help of a male relative. The fathers/partners either died or left home years ago. While the absence of this male presence seems to affect Silvana very little, we can imagine that, for Jair, a strong father-son re- 
lationship might have made a difference. Lacking such support, in order to deal with the challenges of caring for a son with severe psychiatric problems, Jurema would need a creative and persistent professional network offering complex services. Without this sort of backup, and given the precarious nature of available measures, Jurema, tired and at the end of her tether, is easily blamed for her son's disturbing condition.

The ethnographic method focusing on everyday practices forces us, in the end, to look beyond preconceived categories toward the dynamics of 'collectives of care'. The three cases described here demonstrate how care depends on the articulation of various levels, a sort of 'tinkering', in which the individual, the family, the neighbour and the state overlap. Persons with disabilities display different forms of agency, striving for a degree of autonomy: Nina makes herself the hostess of her neighbourhood association and will tell anyone who will listen about how she takes care of herself; Jair has love affairs and envisages his own future; Silvana makes plans for money that she will one day receive. However, the ongoing success of these projects depends on the collaboration of neighbours and acquaintances from their social networks -sources of encouragement, as well as censure and aggression.

In the case of adults with a disability that, in the eyes of the law, leaves them "unable to lead an independent life", it is usually mothers or elderly women who perform the daily caretaking activities, especially in lower-income families. The relative burden and effectiveness of these activities depend, to a great extent, on the convergence of networks in which the woman participates. The collectives of care do not comprise a formal and clearly delimited entity; they are constructed in daily contact, through the flow of information, the exchange of services, mutual recognition, and reciprocal favours.

To complement her efforts in caring for dependent members of the family, a woman may rely, in some cases, on the female network of her extended family. In others, she may have recourse to the community and public services that exist to help her. In still others, the neighbourhood association may prove to be an important axis permitting another sort of collectivization of care. However, when a situation extrapolates the limits of existing resources, the brunt of moral responsibility for failure is easily attributed to the weakest link of the network: the woman/mother, always under suspicion of not being an adequate caretaker.

To sum up, the stories of these different families do not lend themselves to facile generalization. On the contrary. Our aim has been to bring out the subtleties and often unpredictable effects of certain empirically-situated collectives of care characterized by the superposition of personal initiative and variables of class, gender, and generation as well as the solidity (or debility) of different formal and informal support networks. In facing the daily challenge of caring for a person with cognitive or intellectual disabilities, people such as 
Lígia, Edna, and Jurema have long been analysing and, above all, tinkering in creative ways with this complexity. By translating their experience into academic analysis, we hope not only to give visibility to the often-overlooked labour (largely feminine) necessary to promote the well-being of dependent family members. We also hope to help planners and agents of social policy to temper the routine normative approaches that saturate professional manuals, and give value to the tinkering logics that inevitably constitute a fundamental part of their practice.

Received on 9/8/20I7 | Revised on 2/I I/20I7 | Approved on 4/I I/20I7

Claudia Fonseca has an undergraduate degree from the University of Kansas (I967), a Master's degree in oriental studies from the University of Kansas (I969), a doctorate in sociology from the École des Hautes Études en Sciences Sociales (I98I) and a doctorate in ethnology from the Universite de Nanterre (I993). She is full professor of the Universidade Federal do Rio Grande do Sul (UFRGS) and develops research in the following themes: working-class groups, family and gender, anthropology of law, anthropology of science and technology.

Helena Fietz has a Master's degree in social anthropology from Universidade Federal do Rio Grande do Sul (UFRGS) and is currently a doctoral student with a CAPES scholarship at the same institution. She is a researcher linked to the Anthropology and Citizenship Group (NACi) and the Sciences in Life Research Group, focusing on the following themes: disability, care, family, the anthropology of science and technology, and the anthropology of law. 


\section{NOTES}

I This research resulted in the Master's dissertation Deficiência e práticas de cuidado: uma etnografia sobre 'problemas de cabeça' em um bairro popular, defended by Helena Fietz in February of 2016.

2 The law stimulates that the per capita family income of those receiving a BPC should be no more than a quarter of the minimum monthly wage.

3 It is worth stressing an analytical distinction between the circulation of children among members of the extended family and neighbours - that is, people of near-equal status - and the so-called criadagem that has historically involved the exploitation of the domestic labour of poor children by elite families. Scholars such as Moreno (2013) and Leinaweaver (2008), among others, have described the tenuous threshold that separates one form of adoption or fosterage from the other in various parts of Latin America.

4 In Portuguese, onde come um português, comem dois ou três. This is a popular proverb which literally means "where one Portuguese eats, two or three [also] eat", and conveys hospitality by affirming that, wherever food is available, there is always room/food for "two or three" more people. It uses the designation português as a generic identity to rhyme with the word três, 'three'. [Translator's Note]

5 This discussion is aligned with a recent wave of feminist theories of care. Directing their attention toward people with disabilities, or those who care for disabled people, analysts have challenged a first wave of Disability Studies authors who gave central importance to values such as 'autonomy', 'independence' and 'productivity' (as if 'social barriers' were the only obstacle for the person with disability to enter the job market and attain a status of full equality with other citizens) (Diniz 20I2). Based on their own personal experiences, researchers such as Eva F. Kittay (I999) brought the body to the centre of the debate, pointing out that, for many people with impairments, independence as an ideal will never materialise. Thus, reinstating care-givers as central figures in the debate, these researchers underlined the need to break with the individualistic logic of neoliberal society, contemplating 
forms of equality and justice in relations of dependence and interdependence.

6 In total, his monthly allowance amounted to $\mathrm{R} \$ \mathrm{I}, 200.00$, which was considerably above the minimum wage at the time, which was set at $R \$ 880.00$.

\section{BIBLIOGRAPHY}

Ahlert, Martina. (2008). Mulheres de Monte Verde: etnografia, subalternidade e política na relação de um grupo popular de Porto Alegre e o Programa Fome Zero. Master's Dissertation. PPGAS/Universidade Federal de Santa Catarina.

Bellacasa, Maria Puig de la. (20II). Matters of care in technoscience: assembling neglected things. Social Studies of Science, 4I/I, p. 85-106.

Bonetti, Alinne. (2007). "Não basta ser mulher, tem de ter coragem": uma etnografia sobre gênero, poder, ativismo feminino popular e o campo político feminista de Recife/PE. Doctoral Thesis. PPGCS/Universidade Estadual de Campinas.

Bonetti, Alinne. (200I). Novas configurações: direitos humanos das mulheres, feminismo e participação política entre mulheres de grupos populares porto-alegrenses. In: Novas, Regina Reyes \& Kant de Lima, Roberto (eds.). Antropologia e direitos humanos, Niterói: EdUFF, p. I37-20I.

Brites, Jurema \& Schabbach, Leticia (eds.). (2014). Políticas para família, gênero e geração. Porto Alegre: UFRGS/CEGOV. Das, Veena. (2015). Affliction: health, disease, poverty. New York: Fordham University Press.

Diniz, Débora. (2012). O que é deficiência. São Paulo: Brasiliense.

Esquivel, Valeria. (20II). The care economy in Latin America: putting care at the center of the agency. United $\mathrm{Na}$ tions. Series: Undoing knots, innovating for change. New York: United Nations Development Programme.

Fassin, Didier. (2012). Introduction: Towards a critical moral anthropology. In: A companion to moral anthropology. West Sussex: Wiley-Blackwell, p. I-I8.

Fonseca, Claudia. (2002). Mãe é uma só? Reflexões em torno de alguns casos brasileiros. Revista de Psicologia da USP, I3/2, p. 49-68. 
Fonseca, Claudia. (I995). Caminhos da adoção. São Paulo: Cortez.

Hirata, Helena \& Debert, Guita Grin. (2016). Apresentação. Cadernos Pagu, 46, p.7-I5.

Hirata, Helena \& Guimarães, Nadya Araújo (eds.). (2012). Cuidado e cuidadoras: as várias faces do trabalho do care. São Paulo: Atlas.

Junge, Benjamin. (20I7). Uncivil subjects, uncivil women: civic participation, ambivalence and political subjectivity among grassroots community leaders in Porto Alegre, Brazil. In: Alvarez, Sonia E.; Thayer, Millie \& Rubin, Jeffrey W. (eds.). Interrogating the civil society agenda. New Paltz: State University of New York.

Junge, Benjamin. (20I2). NGOs as shadow pseudopublics: grassroots community leaders' perceptions of change and continuity in Porto Alegre, Brazil. American Ethnologist, 39/2, p. 407-424.

Kittay, Eva Federer. (I999). Love's labor: essays on women, equality and dependency. New York: Routledge.

Lavinas, Lena. (20I4). La asistencia social en el siglo XXI. New Left Review, 84, p. 7- 48.

Leite, Marcia Pereira. (2004). As mães em movimento. In: Leite, Marcia Pereira \& Birman, Patricia. Um mural para a dor: movimentos cívico-religiosos por justiça e paz. Porto Alegre: Ed. UFRGS.

Leinaweaver, Jessaca. (2008). The circulation of children: kinship, adoption, and morality in Andean Peru. Durham: Duke University.

Lima, Sheila Silva \& Assis Brasil, Sandra. (2014). Do Programa De Volta para Casa à conquista da autonomia: percursos necessários para o real processo de desinstitucionalização. Physis - Revista de Saúde Coletiva, 24/I, p. 67-88. Mol, Annemarie. (2010). Care and its values: good food in the nursing home. In: Mol, Annemarie; Moser, Ingunn \& Pols, Jannette. Care in practice: on tinkering in clinics, homes and farms. Belefeld: Transcript.

Mol, Annemarie. (2008). The logic of care: health and the problem of patient choice. New York: Routledge. 
Mol, Annemarie; Moser, Ingunn \& Pols, Jeannette. (2010). Care: putting practice into theory. In: Care in practice: on tinkering in clinics, homes and farms. Belefeld: Transcript, p. 7-26.

Molinier, Pascale. (20I2). Ética e trabalho do care. In: Hirata, Helena \& Guimarães, Nadya Araújo (eds.). Cuidado e cuidadoras: as várias faces do trabalho do care. São Paulo: Atlas.

Molyneux, Maxine. (2007). Change and continuity in social protection in Latin America: mothers at the service of the State?. Gender and Development Programme/United Nations Research Institute for Social Development (UNRISD), Geneva, I.

Molyneux, Maxine. (2000). Women's movements in international perspective: Latin America and beyond. New York/London: Palgrave.

Moreno, Alessandra Z. (2013). Vivendo em lares alheios: filhos de criação e adoção em São Paulo Colonial e em Portugal [1765-I822]. São Paulo: Annablume.

Pires, Flavia \& Rego, Walquiria. (2013). Io Anos de Programa Bolsa Família: apresentação do dossiê. Política \& Trabalho, 38, p I3-19.

Proni, Marcelo Weishaupt. (2013). Trabalho decente e vulnerabilidade ocupacional no Brasil. Economia e Sociedade, 22/3, p.825-854.

Razavi, Shahra. (2007). The political and social economy of care in a development context. Conceptual issues, research questions and policy options. Gender and Development Programme/United Nations Research Institute for Social Development (UNRISD), Geneva, I.

Schmidt, Janaina A.C. \& Silva, Mossicléia Mendes da. (20I5). A assistência social na contemporaneidade: uma análise a partir do orçamento público. Revista Katálysis, I8/ı, p. 86-94.

Secretaria Especial de Políticas para as Mulheres (SEPM)/ Ministério dos Direitos Humanos (MMIRDH). (20I6). Gênero e autonomia econômica para as mulheres. Caderno de Formação, Brasília.

Sorj, Bila. (20I6). Políticas sociais, participação comunitária e a desprofissionalização do care. Cadernos Pagu, 46, p.I07-I 28. 
COLLECTIVES OF CARE IN THE RELATIONS SURROUNDING PEOPLE WITH 'HEAD TROUBLES'

242

Sorj, Bila \& Gomes, Carla. (20II). O gênero da 'nova cidadania: o Programa Mulheres Da Paz. Sociologia \& Antropologia, I/2, P. I47-I64.

Tronto, Joan C. (1993). Moral boundaries: a political argument for an ethic of care. New York/London: Routledge.

Vianna, Adriana \& Farias, Juliana. (20II). A guerra das mães: dor e política em situações de violência institucional. Cadernos Pagu, 37, p. 79-II6.

Yazici, Berna. (20I2). The return to the family: welfare, State, and politics of the family in Turkey. Anthropological Quarterly, 85/I, p. I03-I40. 
Palavras-chave Práticas de cuidado; comunidade; relações familiares; gênero; deficiência intelectual.

Keywords

Care practices; community; family relations; gender; intellectual disability.
COLETIVOS DE CUIDADO AO REDOR DE PESSOAS COM 'PROBLEMAS DE CABEÇA':

FAMÍLIA, COMUNIDADE E GÊNERO EM UM

\section{BAIRRO POPULAR DE PORTO ALEGRE}

\section{Resumo}

O artigo reflete sobre as relações e práticas de cuidado que dão sustento ao bem-estar de pessoas com deficiência intelectual que moram num bairro de classe popular da cidade de Porto Alegre (Brasil) em um contexto de políticas públicas incipientes para essa população. Para tanto, realizamos descrição etnográfica da experiência de três mulheres residentes responsáveis pelos cuidados de seus parentes adultos acometidos daquilo que entendem como 'problemas de cabeça' a fim de ilustrar as especificidades de gênero, geração, classe e etnia que permeiam suas práticas. Consideramos que levar em conta as dinâmicas variáveis que subjazem as situações de cuidado assim como a interação dos diversos recursos - familiares, vicinais, estatais

- disponíveis para enfrentar essas situações é um caminho para forjar políticas eficazes no contexto das complexas conjunturas atuais.

\section{COLLECTIVES OF CARE IN THE RELATIONS SURROUNDING PEOPLE WITH 'HEAD TROUBLES': FAMILY, COMMUNITY AND GENDER IN A WORKING- CLASS NEIGHBOURHOOD OF SOUTHERN BRAZIL}

Abstract

In this article, we reflect on the care practices and relationships that contribute to the well-being of people with intellectual disabilities, living in a poor neighbourhood of Porto Alegre (Brazil), in a context of incipient public policies for this population. Through the ethnographic description of the experience of three women from who are responsible for adult relatives with what they call 'head troubles', we aim to illustrate the gender, generation, class and ethnicity peculiarities of their trajectories. We consider that taking stock of the various dynamics at play in situations of care, as well as the interaction of the family, neighbourhood, and public resources available to deal with such challenges, is a fundamental step for forging efficient policies adjusted to the complexities of the contemporary context. 